\title{
Student Engagement: Enhancing Students' Appreciation for Learning and Their Achievement in High Schools
}

\author{
Solmaz Khodaeifaal ${ }^{1, *}$ \\ ${ }^{1}$ Department of Educational Studies and Department of Curriculum and Pedagogy, Faculty of \\ Education, University of British Columbia, Canada \\ *Correspondence: Department of Educational Studies and Department of Curriculum and \\ Pedagogy, Faculty of Education, University of British Columbia, Canada. E-mail: \\ solmaz.khodaei.ca@gmail.com
}

Received: July 10, 2017 Accepted: August 2, 2017 Published: September 20, 2017

doi:10.5296/ije.v9i3.11678 URL: https://doi.org/10.5296/ije.v9i3.11678

\begin{abstract}
Students' perspectives and ideas related to classroom learning seem to be mostly ignored in high schools. Not only does this issue result in both teachers and students struggling in the process of teaching and learning, but students also fail to appreciate the intrinsic value of the curriculum content. It is therefore important to explore the significance of student engagement on their appreciation of learning as well as any positive effects that it might have on their success. This paper has two main aims. First, it provides an overview of the consequence of student engagement and why attending to students' points of view and their engagement in the process of learning might improve their content learning and achievement. Second, it provides a sketch of the attempts made toward the use of technology and social media to motivate and engage students in content learning. Consequently, the paper has three main sections. The first gives succinct descriptions of student engagement in high school. The second part alongside with my own teaching experiences traces the ways that students are helped to develop an appreciation for learning and highlights the importance of the impact of student engagement in learning. The third section interweaves students' interest and engagement with digital media and an appreciation of content learning. In so doing, the paper suggests that social media could be an aid for students to learn the content in the subjects being studied, which connects their in-school context and experience to out of school.
\end{abstract}

Keywords: Student Engagement, Student Learning, Student Achievement, Social Media and Technologies, and High School 


\section{Introduction}

Knowledge about teaching methods and strategies to help students learn and improve has developed significantly in recent years (British Columbia Ministry of Education, 2011). We, teachers and educators, continue to utilize and implement this new knowledge to change the students' learning environments and enhance the quality of education and its impact on student content learning and achievement (Dunleavy, Willms, Milton, \& Friesen, 2012). Although 'the level of students' engagement with science varies considerably across countries and economies" (OECD, 2016b, p. 119), the study of student engagement, specifically intellectual engagement, provides a great opportunity for exploring what types of experiences for adolescents might result in improved abilities and skills for learning and life (Dunleavy, et al., 2012). It is significant that one of the aims of the curriculum in education is to maximize student engagement (Hargreaves, 2005). Therefore, students' engagement, students' points of view and their activity in high schools should be considered for effective improvement towards better achievement in education (Shernoff, Csikszentmihalyi, Schneider, \& Shernoff, 2003; Ministry of Education, 2011; Dunleavy, Milton, \& Willms, 2012).

\subsection{Description of the Problem}

Based on my own teaching experiences, observations, and a review of the literature with regard to student engagement, students' points of view, recommendations, and participation are often not appropriately appreciated by teachers. Students' perspectives, opinions, ideas and other aspects related to their involvement in school seem to be mostly ignored; and only the decisions and points of view of teachers and other adults - school's administrators, policy makers, and parents — seem to be important (Cook-Sather, 2006; Orr \& Olson, 2007; Yonezawa \& Jones, 2009). Not only does this issue seem to result in both teachers and students struggling in the process of teaching and learning, but students also fail to appreciate the intrinsic value of the curriculum content (Pugh \& Phillips, 2011; Emdin, 2016) because they are not intellectually engaged with the content. "Low attendance, achievement and graduation rates" suggest that students struggle at school, which can create problems for teachers.

Results of studies that I reviewed illustrate from the students' perspectives that "they want to be at school, believe they were making a strong effort to do well in their classes, and want to be successful" (Dunleavy, Douglas Willms, Milton, \& Friesen, 2012, p. 6). There seems to be a significant "gap between students' aspirations, their efforts to do well at school, and the marks they were receiving in their classes" (p. 6). Additionally, based on my own teaching experiences, observations, and review of the literature, it appears that students' interests and use of social media such as YouTube ${ }^{\mathrm{TM}}$ and Instagram ${ }^{\mathrm{TM}}$ and their use of digital technologies such as cellphones, tablets, computers, and other devices may not be properly and positively regarded by teachers as a way of learning and making connections between content and students' lived experiences both in and out of school (Sancho, 2009; Emdin, 2016). Therefore, why and how a teacher should address and consider students' perspectives, their points of view in the classroom, and their use of social media is important (OECD, 2014; OECD, 
2016b). In brief, teachers and administrators seem to ignore the students' points of view by only regarding and favoring the views of adult decision-makers (Cook-Sather, 2006; Orr \& Olson, 2007; Yonezawa \& Jones, 2009); thus, students seem to be less intellectually engaged in learning and therefore may not achieve as well as they could.

\subsection{Purpose}

The main purpose of this paper is to explore the importance and impact of student engagement and anticipated appreciation towards the learning of course content, resulting in the improvement of their success in schools. The key question to be explored in this paper is: How can teachers improve students' success and their appreciation of learning content in science? I discuss how teachers might gain from students' perspectives and ideas, and the use of social media might improve students' learning and success. The purpose of this review is not to delve into and discuss all perspectives of student engagement and all aspects of social media with lots of cons and pros. This paper focuses on the positive and efficient impacts of social media on the student's content learning of science.

\subsection{Theoretical Framework}

I will provide a brief description of the learning theory that informs my perspective and the circumstances under which students are able to improve their appreciation of learning the content and, ultimately, their achievement in high school. The theoretical framework that I utilize for this study and experienced in a pragmatic way through my own teaching and learning practices is based on John Dewey's theory of learning. Dewey stated that learning occurs as a consequence of the individual's direct activities and personal experiences (Dewey, 1916). Dewey's "Pragmatic" educational philosophy emphasizes progressive education, a student-centered approach and the need to learn by doing and experiencing reality through a hands-on approach (Ayers \& Schubert, 2012). Students, according to Dewey, are active participants in their own learning and their teachers, as facilitators, should learn together according to democratic principles (Dewey, 1916). Consequently, I argue that if students are not provided with opportunities to express their viewpoints, to take active roles and become more engaged in the process of their learning and experiences, the essential aspects of their learning will be disrupted. It will impede their appreciation of learning and, as a result, their achievement. My study will focus on exploring the conditions under which teachers enhance students' growth of learning in classrooms and aid their success.

\section{Definition of Student Engagement}

Student engagement can be considered within three dimensions: social, institutional, and intellectual aspects. Also, there are several other types of engagement such as cognitive, emotional, behavioral, and psychological (Parsons \& Taylor, 2011). However, I will not provide and review all definitions, types, and aspects of student engagement delivered by proponents and opponents in studies. I will focus on utilizing a definition that matches more with the purpose of my study and accords with the advocates' views and, second, consider the benefits of student engagement toward the students' appreciation of content learning, which 
is a way to enhance their achievement in high schools.

According to empirical studies over the past twenty years, "engagement" has emerged not only as "a strategy for improving educational achievement" but also as "an independently valuable outcome of schooling" in education (Dunleavy \& Milton, 2008, p. 5). It is significant that one of the aims of the curriculum in education is to maximize student engagement (Hargreaves, 2005). Furthermore, student engagement is a significant aspect of teacher self-efficacy and students learning (Schleicher, 2015). The authors of the Canadian Education Association provided one of the most comprehensive and impactful definitions of "student engagement," particularly for adolescent students. They define student engagement as:

The extent to which students identify with and value schooling outcomes, have a sense of belonging at school, participate in academic and non-academic activities, strive to meet the formal requirements of schooling, and make a serious personal investment in learning (Willms, Friesen, \& Milton, 2009, p. 43).

Under this interpretation, the authors identify three dimensions of student engagement "Social Engagement, Academic Engagement, and Intellectual Engagement" (p. 6). This definition and the three forms of student engagement will be utilized in this research paper. The dimensions are described as follows:

Social engagement can be described as "a sense of belonging and participation in school life" (Willms et al., 2009, p. 7). In social engagement, students have opportunities to develop social skills, networks, and constructive friendships, and will eventually like school (Dunleavy \& Milton, 2008). Therefore, in this form of engagement, students are participating in and involved in school activities and extracurricular activities, such as sports and clubs, which might bring the students a strong "sense of belonging" at school.

Academic or institutional engagement refers to the students' "participation in the formal requirements of schooling" or "school attendance" (Willms et al., 2009, p. 7). In other words, academic engagement develops students' personal responsibility, credit accumulation and subsequently their academic success for the purpose of high school graduation and postsecondary destinations (Dunleavy \& Milton, 2008, p. 6). An academically engaged student is defined as a student who rarely skips a class, and studies hard even late at night in order to keep their marks and results at the top (Dunleavy \& Milton, 2008) since they know it is important for their future. In addition, they are on time whether for class attendance or submitting and completing their assignments. With institutional engagement, students have opportunities and chances to improve an "orientation to good work and personal responsibility" (Willms et al., 2009, p. 40). Therefore, schools-where students are under adults' care and supervision - are excellent environments for students to learn skills, rules, and knowledge (Dunleavy, Douglas Willms, et al., 2012). However, all these do not "necessarily mean they love school, or have a deep psychological investment in their learning" (Willms, 2011, p. 3). In short, Willms conveys that institutionally engaged students attempt to comply with the prescribed, assigned, and required affairs in schools regardless of their like or dislike. 
Willms et al. (2009) delineate intellectual engagement as "a serious emotional and cognitive investment in learning, using higher order thinking skills (such as analysis and evaluation) to increase understanding, solve complex problems, or construct new knowledge" (Willms et al., 2009 , p. 7). Students have opportunities to become "knowledge builders, problem solvers, conceptual thinkers, and confident learners" (Dunleavy \& Milton, 2008, p. 6). In addition, intellectual engagement leads students toward the exploration of concepts and understanding of curriculum content, which not only enables them to think critically but also motivates them toward learning (OECD, 2014; 2016c). For example, curious students dig deeper in their science classes, enter science fair projects, and are ultimately interested in working with research scientists while they are still in high school (Dunleavy \& Milton, 2008). Indeed, interest and motivation, effort, and quality instruction are factors of intellectual engagement (Dunleavy, Douglas Willms, et al., 2012). It is this, the intellectual dimension of student engagement, that is the primary focus of this paper. In summary, students are intellectually engaged in schools when they participate in the learning processes in classrooms with thoughtful and deep mental and emotional commitment to learning the content and concepts (Dunleavy \& Milton, 2008; OECD, 2014).

\subsection{Why Student Engagement Is Important in the Process of Learning}

Studies with regard to students' experiences in school and their achievement have underlined the importance of student engagement for learning and teaching in school (Shernoff et al., 2003; OECD, 2016b). Moreover, involvement, engagement, and participation in the process of schooling seem to influence students to achieve successful school completion and bring them "a sense of belongingness and commitment" (Christenson, Sinclair, Lahr, \& Godber, 2001; Shernoff et al., 2003, p. 159). Shernoff et al. state that high engagement and involvement in classrooms reflect a student's "concentrated attention, interest, and enjoyment," which counter boredom, alienation, apathy, laziness, and lack of interest with instruction and education (p. 159). This is the "phenomenological aspect" of student engagement in classrooms (Shernoff et al., 2003). Thus, student engagement in the process of learning in high school classrooms is a significant factor related to students' experiences and outcomes in schools (British Columbia Ministry of Education, 2015; OECD, 2016b).

Shernoff et al. (2003) explored how adolescent students across the US are engaged in high school. They investigated the conditions and environments in which students show greater concentration, interest, and enjoyment in school. The results of their research revealed that the students are involved when they highly utilize and challenge their own tasks and skills, find the instruction relevant to their own experiences, and can personally control the learning environment (Shernoff et al., 2003; 2016). In addition, students are significantly engaged when they are involved with individual or group work activities instead of listening to the teachers' lectures, taking tests, or watching videos in classrooms (Shernoff et al., 2003). Shernoff et al. suggested that "focusing on learning activities," which "support students' autonomy" provides students with a high level of challenge for their tasks and skills (p. 158). 


\section{How Students Are Helped to Develop an Appreciation for Learning}

What are the conditions and ways in high school classrooms in which students are first involved, actually engaged, and then learn through that engagement? We need to explore how we bring it about. "A key place to start is with an examination of the relationships through which students engage in schools, in classrooms, with communities, with their peers, and with the work of learning itself' (Dunleavy \& Milton, 2008, p. 7). These arguments relate to positive perspectives and actions associated with students' views.

Though British Columbia is one of the best education systems in the world (OECD, 2016b; 2016c), with skilled teachers, high rates of student achievement in international and national assessments, and excellent educational facilities, the ministry of education has to transform the education system and consider student engagement with the aim of improving their learning, skills, competencies, and success (British Columbia Ministry of Education, 2015). To this end, researchers and experts agree to support a curriculum that focuses on developing students' skills in "critical thinking, creative thinking, and social and personal responsibility" (p. 1). "They suggested that to prepare students for the future, the curriculum must be learner-centered and flexible and maintain a focus on literacy and numeracy, while supporting deeper learning through concept-based and competency-driven approaches" (p. 1). Twenty-first century students are very different from past generations and are more connected to technology and via social media today; therefore, they need to be more engaged and motivated in learning and becoming competent thinkers and communicators (British Columbia Ministry of Education, 2015). Consequently, "British Columbia's redesigned curriculum honours the ways in which students think, learn, and grow, and prepares them for a successful lifetime of learning where ongoing change is constant" (p. 1).

Students who are effectively motivated to participate and engage in learning with their active roles think critically, communicate clearly, work collaboratively, and develop their creativity (OECD, 2016b). The students should be provided with opportunities that enable them to develop their skills, strategies, and processes over the time of learning, to think critically, to communicate effectively and explicitly, to collaborate respectively, and to be creative (OECD, 2016b). Thus, they need to have autonomy over the actions of learning, which makes them independent decision makers. With these approaches in the $21^{\text {st }}$ century, the rate of student achievement and success increases not only in education but also in society (British Columbia Ministry of Education, 2015). Ultimately, the students with these strengths are becoming educated and better citizens for today and for the future (British Columbia Ministry of Education, 2015).

I elaborate on my own teaching experiences in school in relation to how teachers might regard the students' viewpoints and consider their engagement with the aim of improving their appreciation of content learning and success in school. Teaching physics in the only public international school in my country (in the Middle East) was not an easily acquired experience for me. Initially, I was motivated by the students, who came from various educational systems from different countries around the world and had different levels of knowledge in physics and mathematics. Teaching with minimum resources and educational 
materials to the foreign students - who had diverse objectives and needs in education - was a struggle. Teaching in a traditional educational system to $21^{\text {st }}$-century students, who were familiar with a new and modern educational system, became a challenge for me. Meanwhile, working with other teachers who were completely used to the more traditional methods of teaching was another concern since they were not interested in making any changes. In brief, these issues and challenges became an opportunity not only for me to transform and develop my ways of teaching and learning, but also for the students, who came from a wide variety of knowledge, culture, and education system backgrounds.

These issues prompted me to challenge myself and to contemplate how I could improve not only students' interest and enjoyment in content learning, but also enhance their achievement in school. Moreover, the problems persuaded me to listen to the students' perspectives and opinions. I informally and formally commenced by asking students and collecting their points of view about all the issues related to the subjects, curriculum, textbooks, classes, teachers, and other matters related to school. The students passionately disclosed what they would like to do and have in the classroom, how they would like to study, even how they would like to sit in the classroom, what kind of projects and activities they were interested in, and so on. Because, they had a hope to be heard and have a voice in their own education, I attempted to gain more information from the students themselves.

Cook-Sather (2006) illustrated the emergence of "student voice" in the early 1990s. Not only are students' perspectives on learning, teaching, and schooling significant in their education, but also their active engagement demonstrates that the youth would like to change and improve their education. Students deserve to have an active role in their education (OECD, 2016a). This approach of considering students' engagement and giving students a voice is regarded differently in educational practice since the students are not only and simply engaged, but also have active roles in their own learning processes (British Columbia Ministry of Education, 2015; OECD, 2016a). Cook-Sather describes the relationship between student voice and students" "rights" and "respect" in terms of their education, which is dependent on a practice called "listening." He provides readers with a great opportunity of going not only through, but also beyond the diverse practical aspects of discussions about and critical analyses of student voice.

Students wish to be heard and counted by the teachers and adults in the education system. Student expression and influence transforms teachers into facilitators who, in my educational experience, were in complete authority; students were in a position without any space, possibilities or opportunities, points of view, recommendations, suggestions, or active participation. From my perspective, the underlying premise is that democracy is defined as an equal power relationship between two parties, and in education these parties are the teacher and the students. Moreover, in a democratic society, participation is a citizen's right, and "children are the citizens who arguably have as much right to consideration as any other individual" (Pollard, Thiessen, \& Filer, 1997, p. 2; Cook-Sather, 2006, p. 366). Thus, students should be provided the opportunities to actively design their own education. Teachers should consider what students say and listen to their concerns since, in this way, they are able to recognize the students' struggles. Although Cook-Sather articulates the nature of student 
voice with all its positive and negative aspects, the students' concerns and challenges need more practice and feasible actions in addition to listening.

In the context of teaching in a traditional educational system, even changing the arrangement of the students' desks and chairs in my classes had become a challenge since the conventional educational system did not believe in the new strategies and methods of education. After listening to the students' voices and being aware of their points of view, recommendations, and suggestions, now it was my turn to implement and fulfill their needs and desires. My physics classes were the only classes where the students sat in an elliptical arrangement instead of in rows and columns. After some time, I asked the school principals to adequately provide a physics laboratory for the students as I was going to hold the physics classes in the laboratory, not in a regular classroom. This was a big change in such a traditional system, and I became viewed as a bizarre physics teacher in the school.

I continued to challenge the traditional ways by adding new publications and available online sources to the old and previous resources in the school. I gradually reformed the archaic resources. This change in an educational system in which the books are not chosen by teachers and has a very complicated process by the ministry of education continued my challenge to authority and the old ways. By proving the connection between the physics content and the new resources, which were more updated and related to students' lived experiences and events, made the process more complicated for the school administrators. However, it was an aid to spark the students and gain their appreciation for the physics content through those new resources.

Pugh and Phillips (2011) argue that students do not appropriately and justly appreciate the curricular content. To support their claims, the authors utilized Brophy's model of "content appreciation" (1999; 2008a; 2008b) and put more emphasis on student engagement. According to this model, the teachers need to first rediscover the content worth teaching; second, frame the lessons properly in terms of the content's value in students' lives, which motivate them; and third, scaffold "appreciation" according to students" "motivational zone of proximal development" (Pugh and Phillips, 2011, p. 290). This is a zone in which the students cannot independently solve the problems and make connections; therefore, they need the teacher's assistance (Vygotsky, 1978). Although the relationship between learning and development of thinking in the student is vague and complicated, there is a definite and reciprocal relation (Vygotsky, 1978). The authors demonstrate the importance of relating content to the students' everyday lives, events, and experiences with different actions, supports, and structures, which makes the content more understandable and tangible; thus, it results in students' appreciation of the content. This is how students might better appreciate the learning of content and will more likely follow the sources provided by their teachers.

Some issues and questions, as argued by Pugh and Phillips (2011), emerge since students do not always appreciate the content of the curriculum, which results in teacher frustration. I wonder whether the teachers are able to recognize and address the sources of their frustrations. Brophy recognized the reasons for this frustration and addressed the issues existing in school classrooms. For instance, students may be disappointed and fail to appreciate the value of the 
content. One aspect of this issue is the inclusion of heavy content in the curriculum. What is the content that teachers should care about it? "Teachers and curriculum developers need to be selective in choosing" the curricular content (Pugh and Phillips, 2011, p. 287). This means providing opportunities that enable students to solve problems, see the world differently, and improve their own skills. Students may not be able to change "concepts" to "ideas" like telling the story of a concept, using metaphors, or modeling the concept. Pugh and Phillips (2011) argue that it is the teacher's responsibility to passionately refer the actions and examples that not only convey the purposes and goals of a lesson (concepts), but also make a connection between a lesson and its application to the students' lives (ideas) outside of school. In summary, the authors affirm that the problems related to the appreciation of content are reflected in the teachers' teaching methods and styles.

I argue that teachers sometimes forget that the students are the best "source of data and a force for data collection and analyses" (Yonezawa and Jones, 2009, p. 206). According to the author's research, for instance, one of the students' more controversial research topics was grading policies. They discovered inconsistencies in grading practices between science teachers and mathematics teachers across the school. When the grading practices differ from one subject to another subject, we see more failing grades in one class than the other. However, this topic used teachers' suggestions to solve the issues at hand. I wonder whether students' suggestions are also being used to solve the grading issues. What are the actual reasons for failing grades in science and mathematics subjects? The point here is that the teachers should elicit the students' responses to issues from their critiques and perspectives (Yonezawa and Jones, 2009). Consequently, we would be able to explore the educational challenges from the students' perspectives and points of view and create greater engagement and motivation in classrooms (Yonezawa and Jones, 2009).

Given the numerous required topics in the science and math curricula, there might not be enough time for students to engage and have an active role in classrooms since the majority of the time is given to a teacher-centric environment. Less engagement and less motivation might result in less participation in math and science by students. Another issue that arises for science and mathematics subjects is that "the growing competitiveness for marks as measures of competence for entry to post-secondary institutions detracts from a focus on deep learning" in classrooms (Dunleavy \& Milton, 2008, p. 8). This suggests that policy makers and post-secondary leaders need to cooperate on admission requirements. The issue points out the importance of the students' institutional engagement and their success in schools. We should accept that students are able to recognize their educational needs and make better learning opportunities with their own goals, although this might not be easy. Therefore, teachers should provide opportunities for students to take an active role in the delivery of subject matter as this could raise the students' interests and level of challenge in that subject or classroom (OECD, 2013d; 2016b).

At the international school where I taught, all my students in grade 10 and 11 exhibited innovation and creativity in their physics studies in school, which had unbelievable effects on the students' engagement, enhancement, and academic achievement. The students could passionately demonstrate their abilities, skills, efforts, and capabilities by being involved and 
intellectually engaged in my innovative methods of teaching physics. Researchers argue that "interest provides the basis for becoming engaged with a topic for its own sake" (Shernoff et al., 2003, p. 161). Each of the students, according to their interest (student-selected), had chosen one or two chapters of their textbooks (required topics in their curriculum) to create an innovative project and make something remarkable related to the topic. During the completion of their projects, the students were collaborating with each other not only just for the aim of completing the project but also to learn from each other and teach each other too. They had to find the answers to the physics questions related to their projects throughout their communication, co-facilitation, and collaboration with other students and finally confirm these with me. Although students were working individually on their own project and interest, they had to work together as a group. The more responsible and persistent students were encouraging and helping the others who had a lower level of interest. These approaches transformed learning to a "real-life and real time for students" in the classroom and school (Fullan, 2016, p. 12).

I was listening to them about what they would like to do and what they were interested in, and these are the key considerations to motivate and engage the students. "An interest is always directed towards an object, activity, field of knowledge or goal" (OECD, 2016b, p. 125). I believed in and stepped towards fostering students' intellectual and institutional engagement and improving their success in physics matters. According to PISA 2015 Results (OECD, 2016c),

Students who reported that their science teachers frequently use these methods and adapt their teaching to meet students' needs score higher in science, show stronger beliefs about the value of scientific enquiry, and are more likely to expect to pursue a science-related career than students who reported that their teachers use these methods less frequently (p. 17).

They were continuously receiving my feedback and encouragement; therefore, they could know whether or not they were on the right track. In my view, leading students and keeping them on the right track of learning and performing are the most important factors in teaching and motivating the students. From David Hargreaves' (2009) viewpoint, $21^{\text {st }}$ century teachers are mentors or coaches who provide feedback and comment on the students' work rather than grading it. Teachers should let the students know if they are on the right track or not since most students either are not able to recognize the right track or they do not know that they are off-track when learning and achieving educational goals.

In my physics classes, the students were continuously being encouraged and helped to believe themselves that they could perform well. According to Schleicher (2015), teachers "get students to believe they can do well in school work" which is an efficacy in student engagement. This encouragement gave them a feeling of enjoyment since they were working on their own interests in the subject. They were extremely engaged and concentrated on activities and it was recognizable that they had enjoyable experiences with complete involvement. They were utterly motivated by knowing that their voices, ideas, perspectives, and interests were being heard since the level of their active work and their feeling of satisfaction were being displayed. They were not reluctant to perform and participate in 
physics activities, projects, and the process of learning. They became knowledge builders, problem solvers, conceptual thinkers, and confident learners throughout their learning in the physics classrooms, which are the significant consequences of engagement (Dunleavy \& Milton, 2008). In fact, they could be intellectually engaged in and motivated by their learning. "When students are intellectually engaged, they experience serious personal, psychological, and cognitive investment in learning" (Dunleavy \& Milton, 2008, p. 7).

Their intellectual engagement led them toward exploring physics concepts that enabled them to think critically, motivated them towards content learning, and helped them understand curriculum content. It brought them a feeling of content appreciation since they could connect the relationship between the content and their lived experiences and events, which made physics more exciting for them. I recall that many of the students stated that "time passed very quickly!" or "We did not know where the time went in this class!" These statements reflect their attention and level of focus on the activities in the physics classroom. The extent to which students are involved in and concentrate on activities and learning in classroom demonstrates the level of engagement and "flow" in activities (Csikszentmihalyi, 2007).

Dewey defined "learning" in two ways: first, "the sum total of what is known, as that is handed down by books and learned men" - which is related to traditional education and content learning —, and second, "something which the individual does when he studies; an active, personally conducted affair" - which is associated with progressive education and Dewey's perspective of experience (Dewey, 1916, p. 334). "In educational contexts, deep absorption in activities has been shown to promote optimal learning experiences" (Shernoff et al., 2003, p. 161). During their hands-on work, newly experiencing and learning physics, motivation and involvement were being subsequently generated in their "real-life and real time" (Fullan, 2016, p. 12). I find myself in agreement with Fullan (2016) that these approaches converted learning physics to a "real-life and real time for students" (p. 12). Recently, British Columbia's curriculum was redesigned to better develop student engagement, "content, concepts, skills, and big ideas that foster the higher-order thinking demanded in today's world" (British Columbia Ministry of Education, 2015, p. 3).

Consequently, all those efforts and the lived experiences in my physics classes reflect the key aspects and significant factors of student engagement such as encouragement, interest, enjoyment, creativity, collaboration, communication, and concentration in learning. These key factors effectively impact students' achievement and their success (British Columbia Ministry of Education, 2015; OECD, 2016c). Hattie (2009) realized that "the most powerful single influence enhancing achievement is feedback" (Hattie, 2009, p. 12). In other words, both students and teachers should receive feedback. Students need teachers' feedback and the teachers also need to listen to the students' views, critiques, and evaluations, which can be regarded as the students' feedback for the teachers. The students utilized higher order thinking skills of analysis and evaluation to increase understanding, solve complicated problems, and construct their new knowledge (Willms et al., 2009) in physics. These are good reasons to believe that the engaged students become able to think critically, to develop creativity, to communicate successfully, to work collaboratively, and to enhance their success and achievement (Fullan, 2016). 


\section{A Way to Engage the Students and an Opportunity for Effective Learning}

Adolescents are routinely interested in and actively engaged in various forms of social media such as YouTube ${ }^{\mathbf{T M}}$, Instagram ${ }^{\mathbf{T M}}$, Facebook, and Pinterest, (Schurgin O'Keeffe \& Clarke-Pearson, 2011). "In literature, the term "social media" has been used interchangeably with Web 2.0 tools and social networking software" (Mao, 2014, p. 213). In this paper, social media are defined as new applications and digital technologies using "the internet and Web 2.0 technologies" which allow users to communicate, interact, collaborate, share, manage, and publish (p. 213). The research of Schurgin O'Keeffe \& Clarke-Pearson (2011) demonstrates that social media benefits adolescents by improving their connections, communication, skills, and knowledge. The authors reveal that "the number of adolescents using such sites has increased dramatically" (p. 800). In the 21 st century, social media sites and the use of digital devices have become two important ways for students to feel like they belong.

Recent survey results reported by the American Academy of Pediatrics indicate that:

$22 \%$ of teenagers $\log$ on to their favorite social media sites more than 10 times a day, and more than half of adolescents $\log$ on to a social media site more than once a day. Seventy-five percent of teenagers now own cell phones, and $25 \%$ use them for social media, $54 \%$ use them for texting, and $24 \%$ use them for instant messaging (Schurgin O'Keeffe \& Clarke-Pearson, 2011, p. 800).

These statistics illustrate youth engagement and interest in social media. The results of the studies demonstrate that "students depend on social media in their daily lives for leisure and social connections" (Mao, 2014, p. 213). Indeed, this is not all that engages them in their everyday lives and activities, but the content on the social media sites is also what they are interested in and what motivates them. Although some people believe that social media and the use of digital devices just for texting is isolating people and count them as distractions, these views might change when they see the impacts of media on their adolescents' content learning.

Social media can be an excellent method and tool to motivate and engage students in their learning of content - actually so-called traditional learning. The students should read the books (perhaps in the libraries) and search throughout the books for exploring and learning; however, with appropriate media, they can learn the topic or content in a shorter time through a video or a recorded demonstration on YouTube $^{\text {TM }}$ or Instagram $^{\text {TM }}$. For example, a video of a physics demonstration about one of the complicated topics on YouTube ${ }^{\mathbf{T M}}$ would not only help the students to learn easier and faster but also makes the content more tangible, understandable, and visible. In short, I raise a helpful question: Who would prefer to read a long cookbook instead of watching a short video on YouTube ${ }^{\mathbf{T M}}$ or Instagram $^{\mathbf{T M}}$ for cooking a meal? Therefore, if we bring the contents into media and make them more visible and tangible, it would admittedly motivate and engage the students in content learning.

The recent changes with the use of digital technologies and social media promote virtual active learning and experiences in education. The use of social media such as YouTube ${ }^{\mathbf{T M}}$, 
Instagram $^{\mathbf{T M}}$, and the other applications make learning easier and faster for high school students. It is important to note that most smartphone applications or programs are social and less academic, which should be considered when developing programs with the aim of education. There is a need to bring science and math closer to the students and make these subjects more "user friendly."

Moreover, it is significant to explore the position of science and learning of content knowledge through the use of social media. According to PISA 2015, only 15\% of students reported engaging and following science matters via "blogs," "twitter," and the other social media (OECD, 2016b). About one in ten students visit the websites, computer programs, and applications with virtual labs or technical processes for the aim of learning science (OECD, 2016b). Therefore, the PISA 2015 results reveal the extent to which students are engaged with social media and technology to learn science outside of school. However, the studies illustrate that "educational uses by teachers for classroom teaching and learning are sporadic, while uses by students on their own for learning purposes seem to be abundant but also incidental and informal" (Mao, 2014, p. 213).

Furthermore, Mao's findings (2014) suggest that the students' attitudes and beliefs about social media use in education are positive. Thus, these results demonstrate that the students either have not become interested in science in their classrooms or have not been encouraged by teachers toward the use of media for the aim of learning science. It displays that teachers could not be successful in making science attractive enough in the classrooms that students become interested and engaged with science activities during their free time outside of school (OECD, 2016b). This is the critical point related to teachers and their ways of teaching, engaging, and motivating students in the classrooms. According to the analysis of data from the Teaching and Learning International Survey (TALIS) and the OECD Program for International Student Assessment (PISA), "encouraging teachers ... to lead innovation in the classroom" enhances students' learning and success in the education system (Schleicher, 2015, p. 11). Thus, teachers should attempt to make science more enjoyable through innovative teaching.

Social media benefits most adolescents by enhancing their socialization and communication skills, providing opportunities for "community engagement," "enhancement of individual and collective creativities," "creation of blogs, sites, videos, and so on" and "expansion of one's connections" to the different personal and global issues (Schurgin O'Keeffe \& Clarke-Pearson, 2011, p. 801). Moreover, social media could improve science education by making it more accessible to students and helping them to improve their understanding of the subject. Introducing students to science education via the vast environment of social media can enhance not only their social communication but also their learning of content in science education, thus benefiting not only the students but also the teachers who use their own teaching methods in the classrooms (Schurgin O'Keeffe \& Clarke-Pearson, 2011). For instance, social media provides students with opportunities to collaborate and exchange ideas about learning subjects' content, assignments, and their learning problems (Schurgin O'Keeffe \& Clarke-Pearson, 2011). Furthermore, they receive prompt feedback from their peers by way of collaboration and learning through digital media (Ito et al., 2008). Some 
schools successfully utilize social media "as teaching tools," which have "the benefit of reinforcing skills, written expression, and creativity" (Schurgin O'Keeffe \& Clarke-Pearson, 2011, p. 801).

For example, "in a flipped classroom, students watch the lectures outside of class through the use of screencasts, and class time is spent engaging students through a variety of learning activities" (Schultz, Duffield, Rasmussen, \& Wageman, 2014, p. 1334). This kind of class actually flips the traditional approach of teaching in class and problems practicing and learning at home (Schultz et al., 2014). According to Dewey's approach in education, "to think progressive on the one side and traditional on the other side is a mistake"; hence, "we should look at a deeper level where they can both be integrated" (Ayers \& Schubert, 2012, p. 11). Social media and digital technologies within a flipped classroom approach can transform a classroom from a boring environment to an active, engaging, and motivating one for students (Schultz et al., 2014). The flipped classrooms bring simultaneously traditional and progressive education together into the classroom (Schultz et al., 2014). Moreover, Murphy and Lebans (2008) explores that "the integration of Web 2.0 tools in secondary school classroom teaching increased student engagement with content, quality of assignments, and a sense of responsibility for their learning" (Mao, 2014, p. 214). The results of their studies reveal that "teacher use of Web 2.0 tools and resources has expanded teacher collaboration, changed classroom practice, and increased student engagement in learning” (p. 143-144). Using social media might be a way and an opportunity to innovate teaching and learning science and mathematics. Consequently, social media, which could be YouTube $^{\text {TM }}$ videos or any other programs, applications, and technologies in these examples, can be a helpful and useful tool in the learning of content.

Furthermore, access to social media through the use of their devices already exists in most students' hands, so there is no need to encourage or urge students to use them or not. However, it is the responsibility of the schools to provide students with equal opportunities to access social media and digital technologies. Though equity should be the first concern of teachers and administrators, accommodating students with electronic devices is related to the schools' socio-economic conditions, which is not the focus of this study.

\section{Conclusion}

I wish to highlight and encourage that listening to students and counting on their perspectives and voices provides excellent opportunities not only for increasing students' engagement and enhancement in achievement, but also for the schools' improvement and educational progress (Dunleavy \& Milton, 2008; Dunleavy, Douglas Willms, et al., 2012; Willms et al., 2009). I emphasize that students' issues around their appreciation and learning of content are associated with their level of engagement and their active roles in school classrooms (Pugh \& Phillips, 2011).

Students' engagement brings their voices to the table and gives them space to be heard and counted in the educational system (Cook-Sather, 2006). Students are not the only individuals 
who wish to be heard; we all have a desire to be heard, to have a voice, to display our perspectives, ideas, and viewpoints in which we are living, working, learning, and teaching. It matters who you are when you have a voice that is being heard by some. Therefore, this compels teachers to listen with respect to students' ideas and fulfill their "rights" as learners (Cook-Sather, 2006). With these points of view, my perspective after researching and completing the paper and study was transformed from my lived experiences and beliefs about teaching and learning to one supported by the literature and the scholarly articles. As a physics teacher who was always strongly connected to the subject matter and heavy content, understanding the aforementioned perspectives about students is valuable and noteworthy not only for me, but for all teachers. Here is the moment that a teacher, myself included, might understand why some students do not appreciate the curricular content and how a teacher would be able to recognize, realize, understand, and address the students' learning issues and their struggles in the classroom.

The students' engagement and their points of view, according to the scholarly articles, should be regarded for the aim of positive changes in high schools since educational issues and students learning problems result from their perspectives and critiques (Yonezawa \& Jones, 2009). Indeed, "the most motivated and resilient students are not the ones who think they have a lot of fixed or innate intelligence [but those] who believe that their abilities can be developed through their effort and learning" (Dunleavy \& Milton, 2008, p. 7), and this is exactly what the teachers should consider in their relationships with the students in the classrooms. Teachers are responsible for fostering students' abilities and skills through their struggles in learning (OECD, 2014; 2016b). Through students intellectual engagement, which "is characterized by students putting in extra effort in their studies and being motivated to learn" (Willms, 2011, p. 4), "the teachers are interacting with that positive effort and motivation on the part of students, providing effective learning time, and having relevant, exciting instruction in the classroom" (Willms, 2011, p. 4).

In addition, "when students are intellectually engaged, they experience serious personal, psychological, and cognitive investment in learning" (Dunleavy \& Milton, 2008, p. 7). The point here is that the students are a great source of information, data, and ideas (Yonezawa and Jones, 2009) and are able to develop not only their learning, but also improve schools in which their perspectives and intellectual engagement are significant factors in their educational progress (Dunleavy \& Milton, 2008). Therefore, the effectiveness and value in student engagement is to "get students to believe they can do well in school," "help them value learning," "motivate [those] who show low interest," and "help students think critically" (Schleicher, 2015, p. 42).

Ultimately, if young students are learning, interpreting, and interacting with information in different ways due to the massive proliferation of digital technologies, teachers have a responsibility to evolve in a way that reflects this reality and systematically cultivate the skills and adaptability required for students to navigate the opportunities of modern society. Indeed, using social media can possibly be an aid toward more easily learning the content knowledge in the subjects being studied, which connects students' context in school to out of school (Dunleavy \& Milton, 2008). From my point of view, students' lived experiences 
outside of schools and their interests in using social media and digital technologies can be connected to their curricular content learning in the classrooms.

\section{Acknowledgement}

Thanks for Dr. Steve Cardwell, Professor of Teaching, and Dr. Taylor Webb, Associate Professor, University of British Columbia.

\section{References}

Ayers, W. C., \& Schubert, W. H. (2012). John Dewey Lives: A Dialogue. Schools: Studies in Education, 9(1), 7-26. https://doi.org/10.1086/665019

BC Ministry of Education, Provincial Reports: Retrieved February 2017, from https://www.bced.gov.bc.ca/reporting/province.php

Christenson, S. L., Sinclair, M. F., Lahr, C. A., \& Godber, Y. (2001). Promoting Successful School Completion: Critical Conceptual and Methodological Guidelines. School Psychology Quarterly, 16(4), 468-484. https://doi.org/10.1521/scpq.16.4.468.19898

Cook-Sather, A. (2006). Sound, Presence, and Power: "Student Voice" in Educational Research. Curriculum Inquiry, 36(4), 359-390. https://doi.org/10.1111/j.1467-873X.2006.00363.x

Csikszentmihalyi, M. (2007). Flow and education. Netherlands: Springer Netherlands. https://doi.org/10.1007/978-94-017-9094-9

Dewey, J. (1916). Democracy and education. Champaign, Ill.: Project Gutenberg.

Dunleavy, J., \& Milton, P. (2008). Student Engagement for Effective Teaching and Deep Learning. Education Canada, 48(5), 4-8.

Dunleavy, J., Douglas Willms, J., Milton, P., \& Friesen, S. (2012). The Relationship Between Student Engagement and Academic Outcomes. What Did You Do in School Today? Research Series Report Number One. Canadian Education Association. Toronto.

Dunleavy, J., Milton, P., \& Willms, J. D. (2012). Trends in Intellectual Engagement. What Did You Do in School Today? Research Series Report Number Three. Canadian Education Association. Toronto.

Emdin, C. (2016). For White folks who teach in the Hood ... and the rest of y'all too: Reality pedagogy and urban education. Boston, MA: Beacon Press.

Fullan, M. (2016). Developing Humanity Education's Emerging Role. Principal Connections, $20(2), 10-12$.

Hargreaves, D. H. (2005). Learning for life: The foundations for lifelong learning. University of Chicago Press. 
Hargreaves, D. H. (2009). Intellectual Guru Seeks' System Redesign of Secondary Education (2009), Retrieved from https://www.theguardian.com/education/2009/sep/22/secondary-education-transformatio n-david-hargreaves

Hattie, J. (2009). Visible Learning: A Synthesis of Over 800 Meta-analyses Relating to Achievement. Educational Psychology, 29(7), 867-869. https://doi.org/10.1080/01443410903415150

Ito, M., Horst, H., Bittanti, M., Boyd, D., Herr-Stephenson, B., Lange, P. G., Pascoe, C. J., \& Robinson, L. (2008). Living and learning with new media: Summary of findings from the digital youth project, (November).

Mao, J. (2014). Social Media for Learning: A Mixed Methods Study on High School Students' Technology Affordances and Perspectives. Computers in Human Behavior, 33, 213-223. https://doi.org/10.1016/j.chb.2014.01.002

Murphy, J., \& Lebans, R. (2008). Unexpected Outcomes: Web 2.0 in the Secondary School Classroom. International Journal of Technology in Teaching and Learning, 4(2), 134-147.

OECD (2013d). PISA 2012 results: Ready to learn (Volume III): Students' engagement, drive and self-beliefs. OECD Publishing, Paris. http://dx.doi.org/10.1787/9789264201170-en

OECD (2014). TALIS 2013 results: An international perspective on teaching and learning. OECD Publishing, Paris. http://dx.doi.org/10.1787/9789264196261-en

OECD. (2016a). PISA 2015 results in focus. OECD Publishing, Paris. Retrieved from https://www.oecd.org/pisa/pisa-2015-results-in-focus.pdf

OECD. (2016b). PISA 2015 results (Volume I): Excellence and equity in education (Vol. I). OECD Publishing, Paris. http://dx.doi.org/10.1787/9789264266490-en

OECD. (2016c). PISA 2015 results (Volume II): Policies and practices for successful schools, PISA (Vol. II). OECD Publishing, Paris. http://dx.doi.org/10.1787/9789264267510-en

Orr, A. M., \& Olson, M. (2007). Transforming Narrative Encounters. Canadian Journal of Education, 30(3), 819-838. https://doi.org/10.2307/20466664

Parsons, J., \& Taylor, L. (2011, March). Student engagement: What do we know and what should we do? Edmonton, Alberta, Canada: University of Alberta.

Pollard, A., Thiessen, D., \& Filer, A. (Eds.). (1997). Children and their curriculum. London: Falmer Press.

Pugh, K. J., \& Phillips, M. M. (2011). Helping Students Develop an Appreciation for School Content. Theory Into Practice, 50(4), 285-292. https://doi.org/10.1080/00405841.2011.607383

Sancho, J. M. (2009). Digital technologies and educational change, In A. Hargreaves, A. 
Lieberman, M. Fullan, \& D. Hopkins (Eds.), Second international handbook of educational change(pp. 433-444). Dordrecht: Springer Netherlands.

Schleicher, A. (2015). Schools for 21st-century learners: Strong leaders, confident teachers, innovative approaches, international summit on the teaching profession. OECD Publishing. https://doi.org/10.1787/9789264231191-en

Schultz, D., Duffield, S., Rasmussen, S. C., \& Wageman, J. (2014). Effects of the Flipped Classroom Model on Student Performance for Advanced Placement High School Chemistry Students. Journal of Chemical Education, 91(9), 1334-1339. https://doi.org/10.1021/ed400868x

Schurgin O'Keeffe, G., \& Clarke-Pearson, K. (2011). Clinical Report-The Impact of Social Media on Children, Adolescents, and Families. Pediatrics, 127(4), 800. https://doi.org/10.1542/peds.2011-0054

Shernoff, D. J. (2002). Flow states and student engagement in the classroom (Statement to the California State Assembly Education Committee). Mill Valley, CA: American Sports Institute. Retrieved from http://www.amersports.org/library/reports/8.html

Shernoff, D. J., \& Csikszentmihalyi, M. (2009). Flow in schools: Cultivating engaged learners and optimal learning environments. In R. C. Gilman, E. S. Heubner, \& M. J. Furlong (Eds.), Handbook of positive psychology in schools (pp. 131-145). New York: Routledge.

Shernoff, D. J., Csikszentmihalyi, M., Schneider, B., \& Shernoff, E. S. (2003). Student Engagement in High School Classrooms From the Perspective of Flow Theory. School Psychology Quarterly, 18(2), 158-176. https://doi.org/10.1521/scpq.18.2.158.21860

Shernoff, D. J., Kelly, S., Tonks, S. M., Anderson, B., Cavanagh, R. F., Sinha, S., \& Abdi, B. (2016). Student Engagement as a Function of Environmental Complexity in High School Classrooms. Learning and Instruction, 43, 52-60. https://doi.org/10.1016/j.learninstruc.2015.12.003

Vygotsky, L. S. (1978). Interaction between learning and development. Mind and Society. Cambridge, MA. Harvard University Press, p. 79-91.

Willms, J. D. (2003). Student engagement at school: A sense of belonging and participation: Publications PISA 2000. Paris, France: OECD. Retrieved from http://www.oecd.org/edu/school/programmeforinternationalstudentassessmentpisa/3368 9437.pdf

Willms, J. D. (2011). Student Engagement: A Leadership Priority, III(2). Retrieved from http://www.edu.gov.on.ca/eng/policyfunding/leadership/Summer2011.pdf

Willms, J. D., \& Friesen, S. (2012). The Relationship Between Instructional Challenge and Student Engagement. What Did You Do in School Today? Research Series Report Number Two. Canadian Education Association. Toronto. 


\section{Macrothink}

Willms, J. D., Friesen, S., \& Milton, P. (2009). What Did You Do in School Today? Transforming Classrooms Through Social, Academic, and Intellectual Engagement. First

National Report. Canadian Education Association. Toronto.

Yonezawa, S., \& Jones, M. (2009). Student Voices: Generating Reform From the Inside Out. Theory Into Practice, 48(3), 205-212. https://doi.org/10.1080/00405840902997386

\section{Copyright Disclaimer}

Copyright for this article is retained by the author(s), with first publication rights granted to the journal.

This is an open-access article distributed under the terms and conditions of the Creative Commons Attribution license (http://creativecommons.org/licenses/by/3.0/). 